\title{
Legal Research of the Indigenous People Status Related To Access and Benefit Sharing the Utilization of Genetic Resources Traditional Knowledge and Cultural Expression Traditional In Indonesia According To the Regulation in Indonesia
}

\author{
CHRISTIAN ANDERSEN \\ Faculty of Law Lecturer Maranatha Christian University. \\ Email: andersen.xtian@ gmail.com \\ Tel: +6281320220700 \\ DINDA NOVELIA ASEFA \\ Faculty of Law Student Maranatha Christian University. \\ Email: noveliadinda@gmail.com \\ Tel: +62 813-2461-6108
}

\begin{abstract}
The role of the community in the management of genetic resources and traditional knowledge, folklorecultural expression (GRTKF) as part of the source of creative industry in Indonesia has lack acknowledge and protected enough. The role of the community that uses and do the development of genetic resources armed with traditional knowledge actually give rise to a consequence law the Intellectual Property (IP). Indonesian has not yet been fully aware of it vital role of traditional community as a legal law entity subject and their traditional knowledge, because until now there are also still a lot of debate that which IP classification area that really should protect traditional knowledge. The role of the community continues to be given priority because the people residing in conservation area are people who have for years inhabiting the region. For Indonesian national interests we absolutely need to give IP Law protection of genetic resources and it is the responsibility of the joint between the government and the community to make further formulation deeper in such cases. With IP protection for the development of genetic resources, it is also can give benefits and opportunities since the enhance of database able, integrated and update. It is to clarify IP Law protection against genetic resources earmarked avoid theft ideas and traditional knowledge owned by the traditional community. Legal relations between government, indigenous people (traditional community) and investors should be firmly stated with the implementation of from a related to the GRTKF.
\end{abstract}

Keywords: GRTKF, Indigenous People, and IP Law.

\section{Introduction}

Indonesia is a country with a tropical climate that consist of many genetic resources, Indonesia is also a country with the second largest mega-biodiversity after Brazil. The high level of biodiversity of germplasm because Indonesia has a wide landscape with the spread and condition of geographical area. The high diversity of genetic resources that Indonesia has will provide opportunities for searching, discovering, utilizing, and optimizing uncharted genetic potential. 
It cannot be denied that every country has to dependence on other countries to meet its needs for genetic resources. For developed countries and countries that have the advantage of science and technology will have greater opportunities in utilizing genetic resources (Gorinsky1994). While countries with a many genetic resources have not been able to manage in such a way because of the limitations on Human Resources owned and existing technology, for example Indonesia. Under these circumstances, developed countries with limited genetic resources have gaps and opportunities from the inability of state management with such abundant genetic resources, by cooperating, the developed countries benefit greatly from cooperation in the utilization of genetic resources.

A challenging task for Indonesia as a nation who is rich in the diversity of genetic resources to be able to utilizes in an integrated way and in a continuing way to be able to produce any products by the better quality. Therefore, on March 20, 2006 Indonesia release Law No. 4 of 2006 on adopting International Treaty on Plant Genetic Resources for Food and Agriculture (Agreement on Plant Genetic Resources for Food and Agriculture). Some of the key subjects set forth in this agreement include the following:

1. Regulating access to genetic resources of food crops and agriculture;

2. Preservation of plant genetic resources;

3. Ongoing utilization policy and its implementation;

4. The commitment of the parties to national and international level;

5. Protection of farmers' rights;

6. Multilateral system on access and benefit sharing;

7. Equitable and equitable sharing of benefits within the multilateral system;

8. Increasing institutional and human resource capacity in the field of conservation and sustainable use of plant genetic resources.

\section{Literature Review}

Until now many legal researchers and practitioners in Indonesia are still trying to give the exact definition of an indigenous people, even in laws and regulations there are also many terms related to indigenous peoples, indigenous and tribal peoples, traditional communities, remote indigenous communities, remote indigenous peoples, and to the village term (Pide 2009).

Of various existing terms, a legal term most commonly used in Indonesia is "masyarakat adat" (customary community or widely known as indigenous people). The term "masyarakat adat" used as a form of category groupings by the community called law community (rechtsgemeenchappen) namely the public that all of the members of their community bound as a single unified under the law prevailing in that is worn, customary law (Greer \& Harvey 2004).

The term "masyarakat adat" is the most commonly used because it is closer to the term used in the 1945 Constitution, namely the term of AMAN . Thus giving the impression that this term is most appropriate to the constitution. The term "masyarakat adat" is used in the Human Rights Law, Forestry Law, Water Resources Law, Plantation Law, Environmental Protection and Management Act. Indigenous term began to appear in the Law on the Management of Coastal Areas and Small Islands (Daulay 2011). The definition of indigenous peoples in this law is in line with the definition of indigenous peoples defined by AMAN in 1999, which identifies indigenous peoples as a group of Coastal Communities who have traditionally settled in certain geographical areas due to ties to ancestral origins, strong links with Coastal and Small Islands Resources, and a value system that determines economic, political, social and legal institutions (White 2013).

Indigenous peoples, also known as first peoples, aboriginal peoples or native peoples, are ethnic groups who are the original inhabitants of a given region, in contrast to groups that have settled, occupied or 
colonized the area more recently. Groups are usually described as indigenous when they maintain traditions or other aspects of an early culture that is associated with a given region (Adat 1987).

The community adat law is a group of person living in a region (ulayat) the abode of certain life and the environment, has a fortune of and leader who served the sake of interest of a group (outside and all into the, and having a will and governance. The indigenous people of also listed in the legislations, as in the law number 51960 concerning agrarian regulation, the act of number 41 of 1999 concerning forestry. Customary law in Indonesia has distinctive characters and complexion that are different from other laws. According to F.D.Holleman in his book, there are 4 (four) common traits of indigenous peoples: (a) religious magic, (b) communal, (c) concrete, and (d) cash.

\section{Research Questions}

The State of Indonesia ratified Law Number 11 Year 2013 About Authorization Nagoya Protocol On Access to Genetic Resources and The Fair and Equitable Sharing of Benefits Arising from Their Utilization to the Convention On Biological Diversity, this is certainly should an effective way of providing protection of Indonesia's biodiversity and ensure benefit sharing for Indonesia as a rich resource of genetic resources. In contrast to the benefits sharing, the problem probably occurs when we discuss who in the country has the right to give the access of each Intellectual Property related to biological diversity or traditional knowledge.

\section{Theoretical Framework}

The term of access and benefit sharing itself are the result of the efforts of the United Nations to bridge the interests of developed countries as investors with developing countries that have bio-genetic diversity with the issuance of the Convention on Biological Diversity (hereinafter referred to as CBD) on 5 June 1992 in Rio de Janiero, Brazil. in Article 15 explained that a country has a sovereign right to grant access to other countries to participate in utilizing genetic resources through international treaties by providing fair benefits. Based on the principle of national sovereignty, Article 8 (j) may be regarded as a first step in seeking the protection of traditional knowledge more broadly and paragraph 5 Article 15 The CBD also stipulates that the utilization of genetic resources and traditional knowledge of a country shall be with the permission of the origin country of genetic resources. In 2010, born the Nagoya protocol on access to genetic resources and the fair and equitable sharing of benefits arising from their utilization (protocol of state recognition of access to genetic resources and fair and balanced division of profits arising from its use over) convention on biological diversity. The formulation of the Nagoya protocol on biological resources wealth derived from plants, animals, and microbiology to industrial products, cosmetics, food, medicine, and other purposes. Where this protocol on set fair access to resources for the use of biodiversity, but also regulate how a benefit or benefits also can be enjoyed by the country of origin that biological resources.

\section{Analysis}

The term Indigenous People and its existence in the 1945 Constitution Article 18 B Paragraph (2), the State recognizes and respects the unity of indigenous peoples and their traditional rights as long as they are alive and in accordance with the development of society and the principle of the Unitary State of the Republic of Indonesia.

The role of the community need to be given priority because the people residing in conservation area are people who has for years inhabiting the region because they are really the first party that maybe really know the source and has been inherited many knowledges about traditional knowledge and else. To see Indigenous People as a legal subject, According to Bushar Muhammad the core of the legal alliance, need have the following condition: 
a. The unity of the life that has regularity

b. Settled in a certain area

c. Have rulers, and

d. Has tangible or intangible assets

The Indigenous People's access can be the distinction line between Bioprospecting and Biopiracy that is sometimes hard to distinguish. In 1993, the Convention on Biological Diversity was established in order to promote bilateral agreements between indigenous areas and advanced country's researchers.

After the access, about benefit sharing they have proven successful in helping indigenous areas receive benefits from pharmaceutical companies. However, some argue that these bilateral agreements are not sufficient in preventing biopiracy due to the inability to monitor contracts, adequately inform indigenous people, and ensure that they receive a significant portion of revenue.

For example, The Wapishana people are an indigenous Guyanese and Brazilian Amazonian tribe. The tribe uses a greenheart nut preparation called tipir as a contraceptive and to treat hemorrhage and infection. The tribe uses cunani, which is toxic to fish but harmless to humans, to facilitate fishing. The Wapishana independently identified the usefulness of these plants and has specific rules for their usage, which is meant to be conducted only by Wapishana. They do not believe in the commercial ownership of land or knowledge.

And there is a German named Conrad Gorinsky who was raised on ranch lands near the Wapishana people's land. He studied and received his $\mathrm{PhD}$ in biochemistry at Oxford University and later returned to Guyana to learn about the Wapishana's use of plants. He learned about tipir and cunani from a Wapishana guide and studied the plants' chemical extracts after which he identified two bioactive chemicals with therapeutic potential which he named rupununine and cunaniol. He applied for and was granted patents on both chemicals in both the United States and Europe, and he did so without the consent of the Wapishana. Dr Gorinsky's primary goal in patenting molecules naturally generated by living eco-systems was to demonstrate that the living eco-systems carried a value beyond the logging value of the forest.

The Wapishana were less than thrilled upon hearing about the patents on their revered plants: "When the Wapishana chiefs heard what the biochemist had done, they accused him of stealing the knowledge of their ancestors and elders in order to sell it to pharmaceutical companies. As one Wapishana woman put it, 'This knowledge has always been with the Wapishana. It's part of our heritage and now it is being taken from us without payment. " The Wapishana contested both of Gorinsky's patents but were only able to get the patent on cunaniol revoked. Ultimately though, Gorinsky let all of the patent fees concerning both his cunaniol and rupununine lapse due to the alienation by and pressure of the Wapishana and conservation groups.

Though it may sound like a conspiracy theory, the Indonesian government has taken seriously allegations that foreign researchers have used all kinds of ways including disguising themselves as tourists to steal the nation's genetic resources.

The 2017 ministerial regulation, released in February, stipulates that the government will no longer provide recommendations for foreign researchers to conduct research in less-explored regions prone to natural resources theft such as Papua and Maluku islands.

\section{Discussion}

While the regulation does not impose a total ban on research in those areas, it makes it more difficult for foreign scientists to obtain a permit for research there. Indonesia's protection of genetic resources according Law Number 13 / 2016 about Paten dan Law Number 11/2013 about Ratification of Nagoya Protocol on 
Access To Genetic Resources And The Fair And Equitable Sharing Of Benefits Arising From Their Utilization To The Convention On Biological Diversity. Article 26:

1. If invention pertaining to and / or derived from an genetic resources and / or traditional knowledge, it shall be mentioned clearly and true origin of genetic resources and / or knowledge the traditional in description

2. The provisions of credit is similar with the nagoya protocol that is intended in the context of access benefit sharing as an effort to protects the source genetic resources in terms of traditional knowledge;

3. But unless in practice not disclose clearly and merely arbitrary genetic resources and / or knowledge in a description of the traditional, so section of 132 paragraph 1 ( ) the b juncto article 132 ( ) paragraph 2 , it can be abolished based on judicial decisions by the mechanisms of a lawsuit filed by third parties to the holder of a patent through commercial court.

Also through Law No. 18/2002 on National System in Research, Development, and Application of Science and Technology. This device is reinforced by Head of LIPI Decree No. 3550 / A / 1998 on Research Approval Guidelines by Overseas Researchers.

Unfortunately, there is often no coordination with the regions (local government). So the practice of biopiracy can still happen. other than that of course this is due to lack of knowledge of local indigenous people who are very disadvantaged over this incident. We can learn from India about establishing Traditional Knowledge Digital Library (TKDL) as a National Database Project for Defensive Protection Indonesian Ministry of Environment can act as the data collection base including the traditional society which need to be protected including the disclosure of origin from an invention related to Indigenous Knowledge. Sovereign right concept can be inferred from the clause of Article 26 Law 13/2016 about Patent.

\section{Conclusion}

Indigenous People needs to be involved in:

1. Information Management (Partner with local goverment)

2. Data collector and inventorization (Local Government)

3. Business development (Local government-investor-

Indigenous People).

4. Access to technology (Indigenous People approval).

Indigenous People that we also know as Adat community must have something like government structure, the leadership or be identified as head of customary has authority concerning a prosperous and comfort in society adat law the customary head and really must have sovereignty over its hinterland (land ulayat and through the head of the adat also have full authority to manage, set and managing the relations between residents to nature about GRTKF.

\section{References}

A. Suriyaman Mustari Pide (2009). "Hukum Adat, (Customary Law past, present \& future). Edition first. Pelita Pustaka. Jakarta. Pp. 51-53

Gorinsky, Conrad. Biologically Active Rupununines. Patent US 5569456 A. 29 Oct. 1996. Print. Gorinsky (1994). Conrad. Polyacetylenes. Patent US EP 0610059 A1. 10 Aug., 1994. Print.

Greer, D. and Harvey (2004). B. Blue Genes: Sharing and Conserving the World's Aquatic Biodiversity. London: Earthscan.

http://www.aman.or.id/

http://www.biodiv.org/doc/meetings/tk/wg8j-03/official/wg8j-03-04-en.pdf 
http://www.thejakartapost.com/news/2017/03/20/ri-steps-up-fight-against-biopiracy.html https://www.cbd.int/abs/doc/protocol/nagoya-protocol-en.pdf

Mr. B. Ter Haar Bzn is translated K. Ng. Soebakti Poesponoto, " Asas-Asas dan

Rob White (2013). "Transnational Environmental Crime”, Published 2016, Routledge Taylor \& Francis

Group, London and Newyork, p.238Tolib Setiady. Intisari Hukum Adat Indonesia (dalam kajian kepustakaan). Third Edition: Alfabeta. Bandung. Page 76-77.

Susunan Hukum Adat (1987). (Principles and Composition of Customary Law - Beginselen en Stelsel van Hat Adat Recht) ", the nineteenth edition, (Jakarta: PT.Pradnya Paramita), p. 6

Zinul Daulay (2011). Traditional Knowledge: "Konsep Dasar Hukum dan Praktiknya” (Concepts, Legal Basis, and Practice), Jakarta: Raja Grafindo Persada, p. 88-89. 